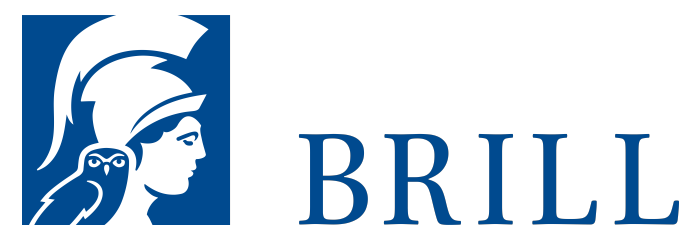

\title{
Reform und Protest
}

Konflikte um die Neugliederung des Kreises Borken in den 196oer und 197oer Jahren

Author: Jan Nikolas Dicke

Wer bestimmt die Leitlinien der Kommunalpolitik? Rat und Kreistag, die als legitimierte Gremien Beschlüsse fassen? Die Verwaltungen, die die Beschlussvorlagen fertigen und den Lokalpolitikern beratend zur Seite stehen? Oder die Bürgerinnen und Bürger als politische Auftraggeber und Mitgestalter? Die Studie geht diesen Fragen am Beispiel der kommunalen Neugliederung nach, die das Land NordrheinWestfalen in den 196oer und 1970er Jahren vollzog. Sie zeigt die Dimension des Reformprojektes und welche Bedeutung die Kreise und Gemeinden dem Erhalt ihrer Selbstständigkeit beimaßen. Der Autor beschreibt deren Reaktionen zwischen Hilflosigkeit und Protest und wie es der Landesregierung trotz allem gelang, ihren Planungsanspruch durchzusetzen.

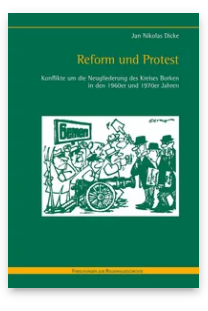

Pages: 482 Seiten, $7 \mathrm{~s} / \mathrm{w}$ Abb.

Language:

German

Subjects: Global History, History

Publisher: Brill |

Schöningh

Series:

Forschungen zur

Regionalgeschichte,

Volume: 74

E-Book (PDF)

Released online:

20 Jan 2020

ISBN: $978-3^{-}$

657-77859-1

List price

Hardback

Publication date:

13 May 2013

ISBN: 978-3-

506-77859-8 
Jan Nikolas Dicke ist Historiker und vertritt z. Zt. die Professur für Organisationsentwicklung im Bildungssystem an der Technischen Universität Dresden.

For more information see brill.com

Order information: Order online at brill.com +44 330 333 0049 | customerservices@brill.com Submission information: brill.com/authors

Titles published by Brill | Fink, Brill | mentis or Brill | Schöningh: +49(o)71 5413279216 | brill@brocom.de 